\title{
German Churches in Times of Demographic Change and Declining Affiliation: A Projection to 2060
}

\author{
David Gutmann, Fabian Peters
}

\begin{abstract}
The problem of declining membership in Germany's churches has been apparent for almost half a century. However, few scientific studies have investigated the respective influences of demographic and church-specific phenomena, as well as the potential impact if present trends continue. To answer these questions, we use a cohort component model and project the membership of each German Catholic diocese and Protestant regional church until 2060. Thus, for the first time we present a projection of church members for each of the 27 Catholic (arch-) dioceses and the 20 Protestant regional churches, as well as for the entire Evangelical Church and the Roman Catholic Church in Germany. We collected data from dioceses, Protestant regional churches and the Federal Statistical Office. Under the assumptions made, the results suggest a continued decline in membership and that by 2060 the number of church members would be half the number of 2017. Protestant Church membership would have shrunk slightly more than Catholic Church membership. We can conclude that church-specific factors (baptisms, leaving, and joining the church) would have a stronger influence on declining numbers than demographic factors. Moreover, demographic change would have a greater impact on registered church membership than on the total population. The proportion of Christians in the population would sharply decrease. Although in 201754.4 percent of the population belonged to one of the two major churches, according to the projection model, only 31.1 percent would be church members in 2060. As our results are not predictions but projections using trend analysis, we show how changed conditions would affect the projected development in five scenarios.
\end{abstract}

Keywords: Church membership - Demographic change · Multi-region cohortcomponent model · Multi-state population projection · Christianity • Roman Catholicism · Protestantism 


\section{Introduction}

Since the early 1970s, Protestant regional churches and Roman Catholic dioceses in Germany have continuously lost members. At the same time, the share of the population that is not a member of either church is increasing. From 1995 to 2017, it has risen from 32.0 to 45.6 percent (Sekretariat der Deutschen Bischofskonferenz 2018, Table 7.24, own calculation). The number of church members fell during the same period by a total of 10.79 million, from 55.64 to 44.85 million. ${ }^{1}$ The development of church membership not only influences the churches' organisation of pastoral care and services, but also the development of church revenue, in particular the church tax. It also raises the question of the long-term financial viability of church personnel and real estate. Moreover, the question of how the number of Catholics and Protestants in Germany will develop in the long term is not only a concern to the churches. In addition to their ecclesiastical duties, churches have taken on numerous social tasks instead of the state, in accordance with the so called subsidiarity principle provided for in the German Basic Law (constitution). They operate kindergartens, adult education institutions, hospitals and care facilities. Including their charities Caritas and Diakonie, the churches are among the largest employers in Germany. If the proportion of the population who are members of one of the two churches continuously decreases, the institutional relationship between society as a whole and the churches will have to be redefined in the long term.

Against this background, we present a projection of the number of members for the Evangelical Church ${ }^{2}$ and Roman Catholic Church in Germany, and for the first time, for each of the 27 Catholic (arch-) dioceses and the 20 Protestant regional churches. Assuming present trends continue, we analyse the impact of demographic as well as church-specific factors, such as baptisms, leaving, and joining the church on future membership development. In the past 10-15 years, membership figures either for all of Germany or for individual Protestant regional churches or Catholic dioceses were occasionally analysed, projected and published (for example, see Hackett et al. 2015; Benz/Raffelhüschen 2013; Benz et al. 2011 or Eicken/ Schmitz-Veltin 2010). Thus far, however, there has been no overview of nationwide developments, which take into account regional and denominational characteristics, as well as the development of the total population. To ensure comparability with the state population projection, we mainly considered the assumptions concerning the demographic development from the federal government's 13th coordinated population projection (Statistisches Bundesamt 2015).

We structure this article as follows: In Section 2, we describe the institutional background and the recent development in church membership in Germany, and place them in the European context. Specifically, we address the demographic as

1 This article refers exclusively to the members of the 20 Protestant regional churches and 27 Catholic dioceses in Germany.

2

The association of the 20 German Lutheran, Reformed and United regional churches (Landeskirchen) forms the Evangelical Church in Germany (Evangelische Kirche in Deutschland; EKD). 
well as church-specific determinants on which the number of church members depends, and derive from their previous development the hypotheses that we want to test. In Section 3, we present the methodology for the projection model. We describe our cohort component model and explain the data used, as well as the underlying assumptions. In Section 4, we present the results. In Section 5, to illustrate the impact of individual determinants on the overall development, we examine five scenarios with changed assumptions. In Section 6, we discuss the hypotheses, and conclude the article.

\section{Church membership in Germany}

\subsection{Religious affiliation and religiosity}

In 2017, slightly more than half of the German population was a member of either the Catholic or Protestant Church. The two denominations are almost the same size: 23.31 million Germans are Catholic; 21.54 million are Protestant. About 2.40 million Germans were members of other Christian denominations (Kirchenamt der EKD 2018a: 4). Beyond Christianity, the second-most widespread faith is Islam, with an estimated 4.7 million followers in $2017 .^{3}$

Registered church membership is brought about by baptism. Although in Germany baptisms predominantly take place during childhood, they can take place at any age. Moreover, not all parents who are church members baptize their children. Furthermore, church members may leave the church of their own volition. People also have the option of switching their registered church membership to another denomination, or to rejoin after deregistration. ${ }^{4}$ In Germany, rules on membership are within the constitutionally protected autonomy of the churches. Therefore, internal church law regulates joining and leaving the church, as well as exclusion from the church. Deregistration from church membership does not affect baptism as an ecclesiastical act. This is why people who rejoin the church are not baptized again (Petersen 2017: 91-92). A baptized individual is registered in the records of the local parish, and this parish informs the state-run registration office about the individual's membership. Because state laws give churches the status of public corporations, they enjoy some privileges, such as establishing religious education at state schools or offering diaconal services in the public welfare system. A particular feature of being a public corporation is the right to levy church taxes on members, which is an income tax surcharge regulated by the state income tax law. ${ }^{5}$ Therefore, paying church tax is compulsory for every church member in Germany with a taxable

3 The number of Muslims in Germany is not recorded statistically. Estimates vary from 4.4 to 4.7 million people. See Halm and Sauer (2017: 16) and Hackett et al. (2015: 237, own calculation).

4

5

In the following, we use the term joining the church for both types of registration.

Depending on the federal state in Germany, the tax rate amounts to 8 percent or 9 percent of the income tax (Petersen 2017: 157-161). The state authority collects the church tax revenue and forwards this money to the Christian churches (Petersen 2017: 11-14). 
income. If an individual resigns from church membership, the state tax authority stops levying the church tax.

The proportion of Catholics and Protestants in the total population varies widely by region for historical reasons (Sekretariat der Deutschen Bischofskonferenz 2018, Table 1.11). In 2017, three out of four church members of a Catholic diocese or a Protestant regional church lived in western or southern Germany. ${ }^{6}$ Because of the anti-church communist regime in the former German Democratic Republic, only 7.2 percent of all church members live in eastern Germany. Overall, the members of Protestant regional churches are distributed more evenly throughout Germany. In contrast, 88.7 percent of Catholics live in southern or western Germany. With a lower proportion of Christians in the total population, the share of people leaving the church from all churches tends to be higher, and the baptism rate (i.e., the ratio of baptisms of children to births) is lower than in regions with a high Christian share in the total population.

The church register shows that the number of Catholic diocese and Protestant regional church members in Germany dropped steadily from 1995 to 2017, from 55.64 to 44.85 million. This decrease corresponds to an overall decrease of 19.4 percent, or 0.9 percent per year since 1995. The share of registered Catholics or Protestants in the total German population decreased from 68.0 percent in 1995 to 54.4 percent in 2017.

In Europe, the absolute Christian population increased from 1910 to 2010 . However, the proportion of the total population fell from 94.5 to 76.2 percent (Hackett et al. 2011: 15). Pollack and Rosta (2015: 93) used the European Values Study to investigate the development of religious affiliation in various Western European countries. The authors show that religious affiliation declined between 1981 and 2008. Burkimsher (2014: 442-443) examined the available data on trends in religious attendance across 24 European countries, with different methods for assessing current trends. She concluded that depending on the method, the indicators "often do not fully agree on whether there is growth, decline, or stability." For some years, there has been disagreement among scientists about the continuous decline in religiousness. The increase in the number of members actively leaving the church, the decrease in (predominantly Catholic) priestly ordinations and the loss of social relevance have been interpreted as clear signs of secularisation (Pollack/Rosta 2015: 89). Beyond advocates of the secularisation theory, some scholars do not foresee a continuous decline in the future, but rather a revival of religion (Pollack/Rosta 2015: 89-97).

The Pew Research Center has calculated that the number of Christians in Europe $^{7}$ would decline from 553.28 million in 2010 to 454.09 million in 2050 (Hackett et al. 2015: 147), and for Germany from 56.55 million in 2010 to 41.64 million in 2050

6 We give a tabular overview of the regional assignment of (arch-)dioceses, Protestant regional churches and federal states in the appendix.

7 The Pew Research Center's list of European states includes 50 countries and territories. These are countries that, according to the definition of the United Nations, belong to the geographical region "Europe" and for which the United Nations Population Division provides general population estimates. 
(Hackett et al. 2015: 237, own calculation). According to their calculations, the proportion of Christians in the European population will fall from 74.5 to 65.2 percent, and the Christian share of the German population from 68.7 to 59.3 percent (Hackett et al. 2015: 147, 237).

For the present study it is important to distinguish between registered church membership and religiosity. Based on the 2005 Generations and Gender Survey, Hackett et al. (2011: 80, own calculation) estimated that there were approximately 56.55 million Catholics and Protestants ${ }^{8}$ in 2010. This number corresponds to a share of 68.7 percent of the German population. That same year, 48.55 million people were officially registered as members of the two major churches, so that the registered share made up 59.4 percent of the total German population. The difference between the survey-based estimate and the church registers of 8.00 million people reveals the empirical weakness of survey data. This is why we use the churches' register data for our projection and focus on the registered membership of the Roman Catholic dioceses and Protestant regional churches in Germany, not on religious trends in society. This difference becomes clear when looking at church attendance: The proportion of service attendees in all registered church members is 4.7 percent for the Protestant churches (Kirchenamt der EKD 2018a: 8, 15, own calculation) and 9.8 percent for the Catholic dioceses (Sekretariat der Deutschen Bischofskonferenz 2018: table 7.3).

\subsection{Determinants}

In 2017, the two major Christian churches in Germany lost 660,000 registered members. The decline was based on demographic factors (births, ${ }^{9}$ deaths, and the migration of church members) and church-specific factors (baptisms, leaving, and joining the church).

\subsubsection{Fertility and mortality}

Fertility and mortality are important variables in the calculation of future population figures. Similarly to other Western European societies, Germany is experiencing a double ageing process: low birth rates since the 1970 s and a steadily increasing life expectancy (Fetzer 2005: 3).

The current total fertility rate - measured per calendar year - in Germany has risen since 1995, from about 1.4 to about 1.6 children per woman. The relationship between religion and childbearing varies across European countries, as Peri-Rotem (2016) analysed for Britain, France and the Netherlands: “These findings suggest that fertility differences by religion also depend on the particular social context of religious institutions in each country." Frejka and Westoff (2008) showed differences

\footnotetext{
8 According to the 2005 Generations and Gender Survey, there are another 1.14 million Orthodox Christians and more than 550,000 other Christians in Germany (Hackett et al. 2011: 80).

9

I.e. children born by a Protestant or Catholic mother.
} 
in fertility between Christians and non-Christians according to the European Values Study results. In general, they show that religiosity is associated with higher fertility, with religiousness measured by the frequency of church attendance and the importance of religion in daily life (Frejka/Westoff 2008: 27-28). The authors found higher fertility for Christian (especially Protestant) women than for women with no religion, as well as for those with an Orthodox affiliation (Frejka/Westoff 2008: 22). Our findings based on the German state income tax statistics (Statistisches Bundesamt 2018d), however, show virtually no difference among Protestants, Catholics and people who are not registered church members. The income tax statistics are a census, and contain information on the taxable income of 52.68 million inhabitants of Germany, who are referred to as tax cases (Statistisches Bundesamt 2018e). Thus, these statistics include almost the entire population aged 20-65 years. As Table 1 shows, the average number of children of non-denominational tax cases is higher than that of denominated tax cases. This evaluation shows that registered church membership does not necessarily allow statements about religiousness. The higher value of tax-admissible children for non-denominational tax cases can probably be explained by deregistrations of Catholic and Protestant parents predominantly aged 25 to 35 and thus an older age structure of the churches compared to the total population. For our projection model, we therefore assume no fertility differences between church members and the total population.

Tab. 1: Average number of tax-admissible children per tax case, 2014

\begin{tabular}{lrrrrc}
\hline & $\begin{array}{c}\text { Number of } \\
\text { tax-admissible } \\
\text { children }\end{array}$ & $\begin{array}{c}\text { Tax cases } \\
\text { with admissible } \\
\text { children }\end{array}$ & $\begin{array}{c}\text { Tax cases } \\
\text { without } \\
\text { admissible } \\
\text { children }\end{array}$ & $\begin{array}{c}\text { Number of } \\
\text { tax cases }\end{array}$ & $\begin{array}{c}\text { Average number } \\
\text { of tax-admissible } \\
\text { children }\end{array}$ \\
\hline Protestants & $4,798,539$ & $2,934,018$ & $8,166,401$ & $11,100,419$ & 0.43 \\
Catholics & $5,326,062$ & $3,222,269$ & $8,784,843$ & $12,007,112$ & 0.44 \\
Others & $7,958,377$ & $5,003,949$ & $12,064,516$ & $17,068,465$ & 0.47 \\
Total & $18,082,977$ & $11,160,235$ & $29,015,760$ & $40,175,995$ & 0.45 \\
\hline
\end{tabular}

Source: own calculation based on Statistisches Bundesamt (2018d).

Concerning mortality, several studies do not support differences between members of the two major churches and the total population in Europe. Lerch et al. (2010: 235) show for Switzerland that members of the Catholic and Protestant churches have an intermediate level of mortality. Non-members of a Christian church have the lowest life expectancy. In contrast, life expectancy among members of other Christian churches is highest (Lerch et al. 2010: 235). Goujon et al. (2017: 56) also do not assume any differences in mortality between church members and nonmembers for their study on church membership in Austria until 2046. They justify their approach with unavailable data. In the case of Germany, there is also no data available. 


\subsubsection{Migration}

In a special evaluation for the two major churches, the Federal Statistical Office calculated confessional migration flows from the local-level migration statistics to the church organisational structures (Statistisches Bundesamt 2018c). We distinguish between internal and external migration. Internal migration refers to migration of Catholics (and Protestants) within Germany from one diocese (and Protestant regional church) to another. External migration refers to migration beyond the borders of Germany. For Germany as a whole, internal inflows equal internal outflows. Depending on the Catholic diocese or Protestant regional church, internal migration flows can lead to either gains or losses in membership. For Catholic dioceses and Protestant regional churches with a lower denominational share than others, internal migration flows lead to a positive migration balance because immigrants are more likely to belong to the corresponding denominations than emigrants. Figure 1 shows the differences between the Protestant and Catholic churches with respect to their external migration balance. ${ }^{10}$

Fig. 1: Balance of Catholic and Protestant external immigration and emigration, 1991-2015

Balance of immigration and emigration

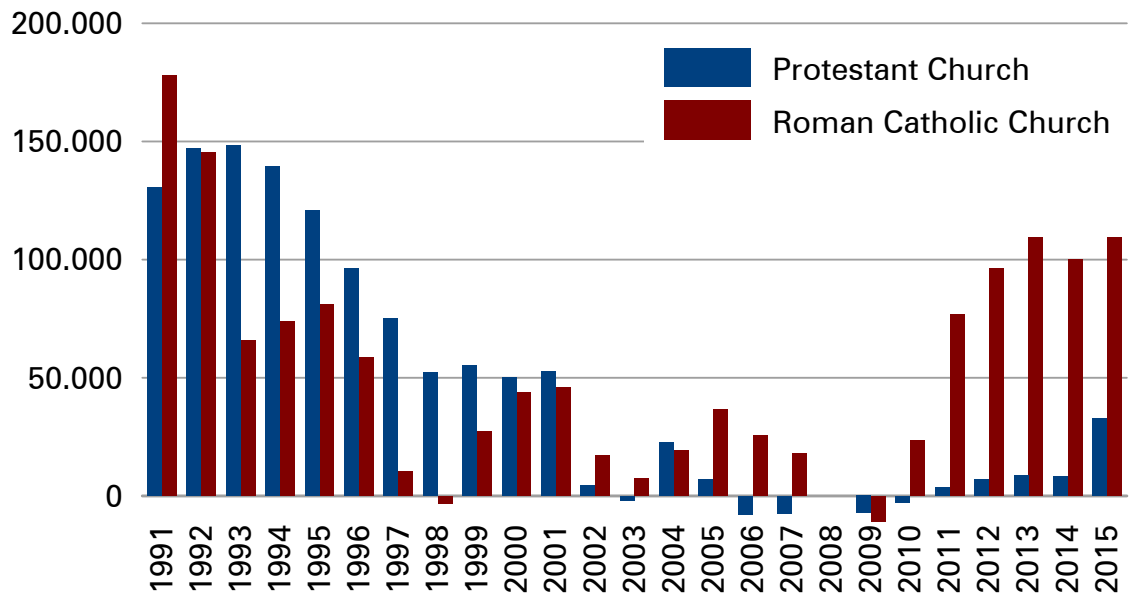

$-50.000$

Year

Source: own calculation based on Statistisches Bundesamt (2018c).

\footnotetext{
10 The difference between Protestant or Catholic church members who move to Germany and those who move away from Germany, and officially register their church membership. To what extent non-Germans who are not aware of a church tax liability from their country of origin state their confession upon entry is not the subject of this study. For Christian internal migration, it cannot be ruled out that, at least in the past, before joining the state-automated reporting system (OSCI XMeld), religious registration was not, or was not stated correctly, in the framework of relocations within Germany.
} 
The high external migration numbers for Protestant Christians before the turn of the millennium was due to the migration of German descendants from countries of the former Eastern Bloc (so-called Russia Germans). These migratory movements are now completed, and should not play a role in the long-term projection (Eicken/ Schmitz-Veltin 2010: 582). Migration from southern and eastern Europe has strongly influenced Catholic external migration flows since 2011. These migrants are mainly from the predominantly Catholic countries of Italy, Croatia, Poland, and Spain. However, as demographic trends in these European countries are similar to those in Germany, the potential for people of migrant age will also decline in the coming decades (Statistisches Bundesamt 2015: 38).

Strong refugee migration in 2014 and 2015, and changes in the survey method in 2016, limit the comparability of the database in these years. For this reason, we consider the period between 2000 and 2013 without the year 2008, which was affected by a statistical adjustment. In this period, the external migration surplus of Germany amounted to 2.22 million people. Of these individuals, 0.13 million (5.9 percent) were members of the Protestant Church, and 0.51 million (23.0 percent) of the Catholic Church.

\subsubsection{Baptisms}

As baptism establishes church membership, baptism behaviour is crucial to the development of registered membership. In the early 1990s, almost 300,000 Catholic and 300,000 Protestant baptisms took place in Germany each year; in 2017, there were only 170,000 Catholic and 176,000 Protestant baptisms. However, the absolute number of baptisms is not very meaningful. A more meaningful indicator is the ratio of the number of Catholic (Protestant) baptisms of children and the total number of children a Catholic (Protestant) mother gives birth to in one year. ${ }^{11}$ If this indicator is 100 percent, the development of baptisms of children corresponds to that of the live births by Catholic or Protestant mothers. If the indicator is lower, subsequent age cohorts of Catholics (Protestants) are smaller than they would be simply due to the demographic trend. If it is higher, subsequent age cohorts are larger than the number of children female church members give birth to in one year. This indicator varies regionally between the 27 Catholic (arch-)dioceses and 20 Protestant regional churches, between 40 percent and 106 percent. ${ }^{12}$ Although these regional baptism rates vary widely, they have been constant since the beginning of the 2010s in the respective Catholic dioceses and Protestant regional churches (Verband der Diözesen Deutschlands 2018; Kirchenamt der EKD 2018b; own calculation).

\footnotetext{
${ }^{11}$ According to German law, children up to the age of 14 are not allowed to choose their own membership in a church. This is why we understand baptisms up to the age of 14 as baptisms of children.

12 We compare all children a Protestant or Catholic mother gives birth to with all baptisms of children up to the age of 14 which take place in the same year. Thus, the numerator and the denominator do not relate to the same time, but form a good benchmark.
} 
Compared to the baptisms of children, baptisms of adults have less influence. In 2017, 85.9 percent of all baptisms took place during the first six years of life. The two denominations show differences in baptism behaviour. Although 93.8 percent of all Catholics are younger than six when they are baptized, only 78.2 percent of all Protestants are baptized before the age of six. Another 14.7 percent of Protestant baptisms take place in the 10 years thereafter until the $16^{\text {th }}$ birthday -9.7 percent between the ages of 12 and 15, around the age of confirmation. In the Catholic Church, we observe a slight increase in baptisms at the age of communion, around the ninth year of life. In total, 4.5 percent of all Catholic baptisms take place between the ages of 7 and 15. However, Catholic confirmation, which takes place at about the same age as Protestant confirmation, does not lead to an increase in baptisms (Verband der Diözesen Deutschlands 2018; Kirchenamt der EKD 2018b; own calculation).

\subsubsection{Joining and leaving the church}

In addition to baptisms, the balance of people who join or leave the church also influences membership development. In both denominations and in all German regions, more people leave the church than join. Annually, about 30,000 people join the Protestant Church and 10,000 people join the Catholic Church. In both denominations, the number of people joining the church has hardly changed over time. In contrast, Figure 2 shows that the number of members leaving the church deviates from year to year. However, it follows similar trends in both churches, and in all regions of Germany at different levels. The number of members leaving the church is higher in the Protestant Church than in the Catholic Church.

The balance of people joining and leaving the church is crucial for the development of registered membership. If we also take baptisms of adults into consideration, the results of the two denominations are more similar. The almost 20,000 Protestant baptisms of adults clearly outweigh the approximately 3,000 Catholic baptisms of adults, so that the balance of people leaving the church and those joining the church, including baptisms of adults, is about the same.

The ratio of members leaving the church and church members fell steadily from the early 1990s (Protestant: 1.3 percent, Catholic: 0.7 percent) until 2005 (0.5 percent, 0.4 percent), but has been rising again since then, peaking in 2014 (1.2 percent, 0.9 percent; Sekretariat der Deutschen Bischofskonferenz 2018, tables 7.24 and 7.25). Since 2014, the ratio has remained relatively high. Particular events strongly influenced the development: the introduction of the solidarity surcharge in 1991, debates regarding the history of sexual abuse in the Catholic Church in 2010, ${ }^{13}$ the public controversy around the generous lifestyle of the Bishop of Limburg in 2013, and the introduction of the amended deduction of the church tax on capital gains in 2014. In addition, there are regional disparities. The church-leaving ratio is particularly high in large cities, such as Berlin, Hamburg and Munich, but the ratio is lower

$\overline{13}$ The sexual abuse scandal in 2010 only led to an increase in Catholics, but not of Protestants, leaving the church. 
Fig. 2: Development of people joining and leaving the church, 1991-2017

People joining and leaving the church

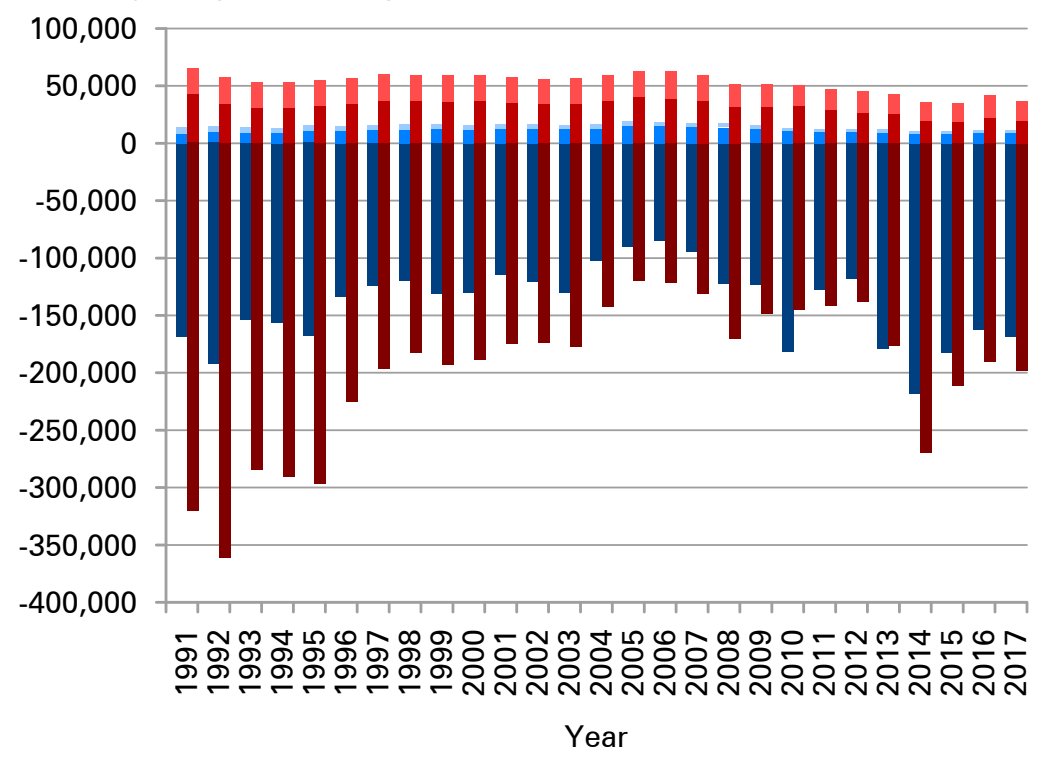

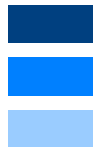

Members leaving Catholic Church

People joining Catholic Church

Members leaving Protestant Church

Baptisms of adults Catholic Church

People joining Protestant Church

Baptisms of adults Protestant Church

Source: Kirchenamt der EKD (2018b); Verband der Diözesen Deutschlands (2018).

in regions with a high proportion of registered church members among the total population.

If we calculate the age- and gender-specific number of members leaving the church in relation to the respective cohort strength, we observe differences in deregistration behaviour. For the whole of Germany, Figure 3 shows an above-average likelihood during the working life between the ages of 20 and 60 . The highest likelihood of leaving the church is approximately between the 25th and 35th year of life. In all Catholic dioceses and Protestant regional churches, more men than women leave the church (Riegel et al. 2019: 182).

\subsubsection{Summary: Effects of determinants}

If we consider the influence of the individual determinants coherently, we can intuitively explain the proportion of Catholic and Protestant church members in the total population by age. In 2017, 54.4 percent of the overall German population was a member of one of the two major churches. However, Figure 4 shows that church affiliation varies greatly between the different age cohorts. The increasing church affiliation up to the age of 15 is based on a biographical effect. The denominational 
Fig. 3: $\quad$ Age- and gender-specific ratio of leaving the church in 2017

Ratio of members leaving the church

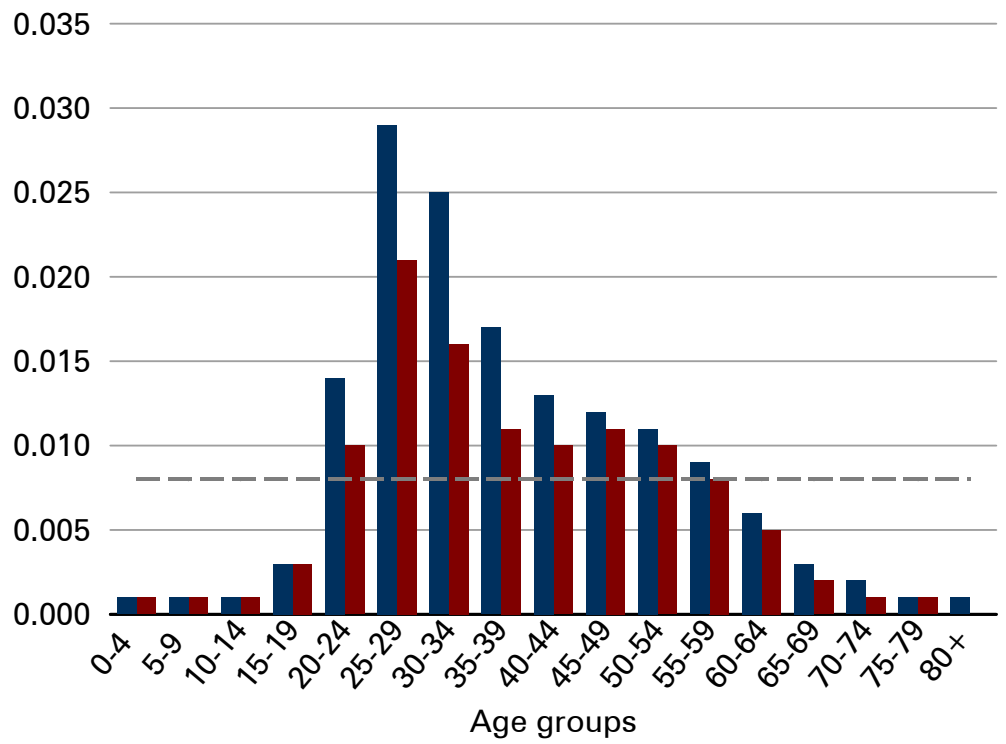

Men Women - - Average ratio of members leaving the church

Source: own calculation based on Kirchenamt der EKD (2018b); Verband der Diözesen Deutschlands (2018).

shares grow due to baptisms in childhood and adolescence. As most baptisms take place not by birth, but during infancy, we see a particularly strong increase to about 40 percent during the first three years of life. By the age of 15, additional baptisms lead to a slower increase to approximately 60 percent of the total population. Up to the age of 25 , the proportion of church members stagnates. In the following 15 age cohorts, the level decreases to about 50 percent of the total population. This change is mainly due to deregistration. Especially in the case of Protestant regional churches, the decline would be even stronger if joining and baptisms of adults did not counteract the decline. From the age of 40 , the share of people registered as members of one of the two churches continuously rises again. At the age of about 70 years, the proportion reaches the level of 15-25-year-olds. More than two-thirds of the people older than 70 in 2017 were members of one of the two major churches, and three quarters of those older than 80 . The high proportion of church members in the older population is because these age cohorts were almost all baptized as infants, and only very few left the church.

\subsection{Hypotheses}

We examine whether and how the decline in membership will evolve in the long term and how it would affect the overall population if present trends continue. If 
Fig. 4: $\quad$ Proportion of registered church members in the population by age in 2017

Proportion of Protestant and Catholic church members

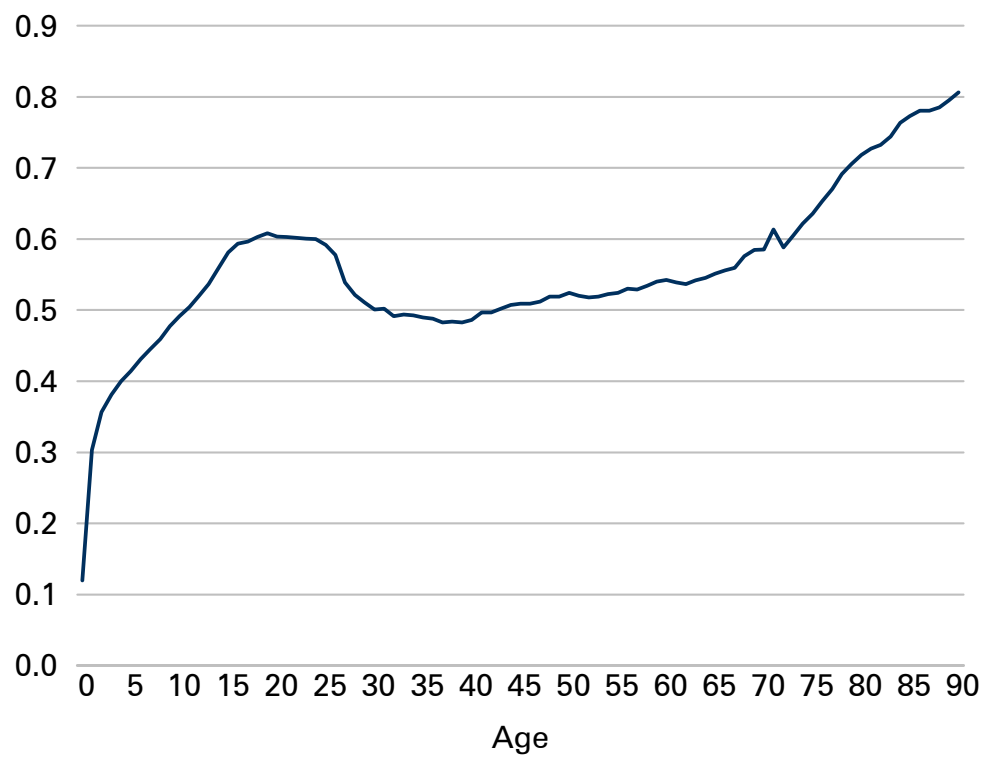

Source: own calculation based on Kirchenamt der EKD (2018b); Verband der Diözesen Deutschlands (2018); Statistisches Bundesamt (2015, 2018b/c).

we follow the argument of the churches, the decline in membership is mainly due to the general population development, that is, demographic changes. Thus, in a 2018 press release, the EKD calculated that more people joined the church than actively left. It compared the number of people who were baptized or joined the church with the number of people leaving the church (i.e. deregistering). However, the high number of Protestant deaths is responsible for the overall membership decline (Kirchenamt der EKD 2018c). This argument establishes connections between different factors which we must disentangle. In addition to natural effects of demographic changes (i.e., the difference among deaths, births, and the migration balance) at the individual decision-making level, church-specific factors, such as baptisms and people joining and leaving the church, play a role. Registered church membership does not begin at birth, but at baptism. Consequently, church-specific factors compound the decline due to demographic changes. This is why we test hypothesis 1:

Hypothesis 1: If the trend of recent years continues, the Protestant and Catholic churches in Germany will continuously lose members by 2060 in both absolute terms and relative to the total population of Germany.

If we distinguish between demographic and church-specific decreases in membership, the following picture emerges in absolute numbers for 2017: 651,000 deaths of Protestant or Catholic church members, compared to 415,000 children given birth to by a Protestant or Catholic mother (Verband der Diözesen Deutschlands 2018; 
Kirchenamt der EKD 2018b; own calculation). We add to this number the external migration of church members, who made up a positive balance of 28,000 . Thus, due to demographic factors, the decline in membership was 208,000 in 2017. This decrease represented 0.5 percent of all church members. Concerning the total population, there were 785,000 births and 933,000 deaths (Statistisches Bundesamt 2018a). We additionally observe a positive external migration balance of 415,000 . This leads to a population increase of 267,000 people, or 0.3 percent of the total population. While the churches are facing a demographic loss, the overall population has a demographic surplus. The contrary development is mainly because only a fraction of migrants registers as members of one of the two Christian churches. From this finding, we derive hypothesis 2:

Hypothesis 2: Even if we only take into account the development of demographic factors in recent years, the decline in membership of Christian churches will be greater than the decline in the total population.

Concerning the decline in church membership, we must also pay attention to church-specific influences. For illustrative purposes, we use the data for 2017: 365,000 members leaving the church are up against 36,000 people joining and 21,000 baptisms of adults. In addition, despite 414,000 confessional births, only 324,000 baptisms of children took place. Due to church-specific influences, the Protestant and Catholic churches in Germany lost 398,000 members (0.9 percent). Church-specific factors had nearly twice as much impact in 2017 as demographic factors, which leads us to hypothesis 3 :

Hypothesis 3: If the trend of recent years continues, church-specific factors will have a greater impact on membership development than demographic factors.

Finally, for the varying intensity of church-specific factors, the distribution of church members throughout Germany in particular depends on internal migration flows of church members. We observed the highest losses because of internal migration in Catholic dioceses and Protestant regional churches with a high share of the population belonging to the corresponding denomination. Moreover, we can show that Catholic dioceses and Protestant regional churches which benefit from high internal migration (such as the dioceses of Hamburg and Berlin) have the highest losses due to church-specific influences. Thus, the Catholic dioceses and Protestant regional churches benefit only to a limited extent. From this finding, we derive hypothesis 4:

Hypothesis 4: If the trend of recent years continues, regional disparities in the distribution of Protestants and Catholics in Germany will weaken by 2060.

\section{Data and method}

We project the membership of each Protestant regional church and Roman Catholic diocese in Germany, as well as the remaining total population, from the base year 2017 until 2060. In line with the multi-state population projection by the Federal Statistical Office of Germany, our projection is based on the cohort-component method with deterministic assumptions (Statistisches Bundesamt 2015: 27). This is the most 
widely-used method, based on the work of Cannan (1895), Bowley (1924) and Whelpton (1928) (George et al. 2004: 571). Leslie (1945) developed the component method in matrix notation as it is used today. The cohort-component method, along with trend extrapolation and structural models, are among the objective population projection methods that are to be distinguished from subjective methods. These objective methods, which are also used together, make a selection necessary, for example with regard to the data source, projection method, and assumptions (George et al. 2004: 562). Rogers $(1967,1975)$ further developed the cohort-component model into a multi-regional model. Rees and Wilson (1977) complemented this system and introduced a model that describes population stocks and flows based on accounts, thereby using the benefits of accounting principles. Based on this work, we use a multi-region cohort-component model. In addition to the demographic factors, we supplement the church-specific factors. Due to the large number of subpopulations - 27 Catholic dioceses and 20 Protestant regional churches - that are in interaction with each other, we develop a multi-church cohort component model with interregion rates and regional immigration and emigration flows.

\subsection{Data}

We use data from the Federal Statistical Office, as well as from the Protestant regional churches and Roman Catholic dioceses. We calculate the total population of Germany in the base year 2017 with help of the population update from the federal government (Statistisches Bundesamt 2019). We use assumptions on fertility, external migration balance and further life expectancy from the 13th coordinated federal population projection. We choose a middle-case scenario of the variants containing fertility and external migration balance, and assume a combined permanent total fertility rate of 1.5 and a total external migration balance of 150,000 (Statistisches Bundesamt 2015). We assume a linear increase in life expectancy for men from 78.3 to 84.8 years from 2017 to 2060 , and for women from 84.6 to 88.8 years. ${ }^{14}$ According to the findings described in Section 2.2.1, we assume no differences in fertility and life expectancy between members and non-members of the two churches.

Church-specific data on the age- and gender-specific distribution of members who were baptized, joined, and left the church in the dioceses and Protestant regional churches come from the registries of the 20 Protestant regional churches and 27 Catholic dioceses. The technical procedures and data collection of these registries are very different. Therefore, the nationwide coordinated data collection was associated with complex data processing. Nearly all of the 47 dioceses and regional churches provided an age- and gender-specific distribution of their members and of the people who left, joined, and were baptized in the years 2013-2017. Therefore, the present data are unique in scope and level of detail.

$\overline{14}$ Further life expectancy at birth corresponds to variant L1 of the multistate population projection by the German Federal Statistical Office. 


\subsection{Projection model}

The starting point is the gender- and age-specific structure of the total population $\mathrm{p}_{\mathrm{t}}$ in the base year $\mathrm{t}$ :

$$
\boldsymbol{p}_{\boldsymbol{t}}=\left(p_{t, 0}^{f}, \ldots, p_{t, a}^{f}, \ldots, p_{t, 100}^{f}, p_{t, 0}^{m}, \ldots, p_{t, a}^{m}, \ldots, p_{t, 100}^{m}\right) .
$$

The exponent $\mathrm{f}(\mathrm{m})$ describes the female (male) population. $\mathrm{p}_{\mathrm{t}, \alpha}$ represents the number of people in period t who are $\alpha$ years old. The maximum age to reach is 100 , so that the row vector $\mathrm{p}_{\mathrm{t}}$ contains 202 entries. We divide the total population $\mathrm{p}_{\mathrm{t}}$ at time $t$ into the sum of the members of the 28 Roman Catholic dioceses $\mathrm{rc}_{\mathrm{i}, \mathrm{t}}$, the 20 Protestant regional churches $\mathrm{pc}_{\mathrm{i}, \mathrm{t}}$ and the remaining population $\mathrm{rp}_{\mathrm{t}}{ }^{15}$ The remaining population represents the share of the total population of Germany who belongs to neither of the two major churches:

$$
\boldsymbol{p}_{\boldsymbol{t}}=\sum_{i=1}^{28} \boldsymbol{r} \boldsymbol{c}_{\boldsymbol{i}, \boldsymbol{t}}+\sum_{i=1}^{20} \boldsymbol{p} \boldsymbol{c}_{\boldsymbol{i}, \boldsymbol{t}}+\boldsymbol{r} \boldsymbol{p}_{\boldsymbol{t}}
$$

The membership of the Catholic Church in Germany is the sum of the members in the 28 Catholic dioceses $\left(\sum_{i=1}^{28} r c_{i, t}\right)$. The nationwide Protestant membership corresponds to the sum of the members of the 20 regional Protestant churches $\left(\sum_{i=1}^{20} p c_{i, t}\right)$. We project each subpopulation until the year 2060. The procedure is the same for the Catholic dioceses and the Protestant regional churches. For calculating the membership of a diocese $\mathrm{rc}_{\mathrm{i}}$ in the following year, we correct for baptisms $\left(\mathrm{b}_{\mathrm{rc}_{\mathrm{j}}, \mathrm{t}}\right)$, mortality, people joining the church $\left(\mathrm{e}_{\mathrm{rc}_{\mathrm{i}}, \mathrm{t}}\right)$, members leaving the church $\left(\mathrm{dr}_{\mathrm{rc}_{\mathrm{j}}, \mathrm{t}}\right)$ and migration $\left(\mathrm{m}_{\mathrm{rc}_{\mathrm{j}}, \mathrm{t}}\right)$ during the year so that:

$$
r c_{i, t+1}=r c_{i, t} * L M_{i, t}+b_{r c_{i}, t}+e_{r c_{i}, t}+m_{r c_{i}, t}-d r_{r c_{i}, t}
$$

$\mathrm{b}_{\mathrm{rc}_{\mathrm{j}}, \mathrm{t}}, \mathrm{e}_{\mathrm{rc}_{\mathrm{i}}, \mathrm{t}}, \mathrm{dr}_{\mathrm{rc}_{\mathrm{i}}, \mathrm{t}}$ and $\mathrm{m}_{\mathrm{rc}_{\mathrm{i}}, \mathrm{t}}$ are row vectors, structured correspondingly to $\mathrm{p}_{\mathrm{t}}$. $\mathrm{LM}_{\mathrm{t}}$ is the valid Leslie Matrix in that contains the age- and gender-specific fertility ratios (fr) and survival probabilities (sp). ${ }^{16}$ The $202 \times 202-$ matrix is structured as follows:

15 Concerning the Catholic Church in Germany, we consider the official district of Oldenburg, which actually belongs to the diocese Münster, separately along with addition to the 27 (arch-) dioceses. This is why we handle 28 Catholic subpopulations.

16 The technical procedure we follow is based on Bonin (2001: 245-249). 


$$
\boldsymbol{L M}_{\boldsymbol{i}, \boldsymbol{t}}=\left[\begin{array}{ccccccccccccccc}
0 & s p_{i, t, 0}^{f} & & 0 & 0 & \cdots & 0 & 0 & \cdots & 0 & 0 & 0 & 0 & \cdots & 0 \\
\vdots & & \ddots & & \vdots & & \vdots & \vdots & & \vdots & \vdots & \vdots & \vdots & & \vdots \\
0 & 0 & & s p_{i, t, 14}^{f} & 0 & \cdots & 0 & 0 & \cdots & 0 & 0 & 0 & 0 & \cdots & 0 \\
f r_{t, 15}^{f} & 0 & \cdots & 0 & s p_{i, t, 15}^{f} & & 0 & 0 & \cdots & 0 & f r_{t, 15}^{m} & 0 & 0 & \cdots & 0 \\
\vdots & \vdots & & \vdots & & \ddots & & \vdots & & \vdots & \vdots & \vdots & \vdots & & \vdots \\
f r_{t, 49}^{f} & 0 & \cdots & 0 & 0 & & s p_{i, t, 49}^{f} & 0 & \cdots & 0 & f r_{t, 49}^{m} & 0 & 0 & \cdots & 0 \\
0 & 0 & \cdots & 0 & 0 & \cdots & 0 & s p_{i, t, 50}^{f} & & 0 & 0 & 0 & 0 & \cdots & 0 \\
\vdots & \vdots & & \vdots & \vdots & & \vdots & & \ddots & & \vdots & \vdots & \vdots & & \vdots \\
0 & 0 & \cdots & 0 & 0 & \cdots & 0 & 0 & & s p_{i, t, 99}^{f} & 0 & 0 & 0 & \cdots & 0 \\
0 & 0 & \cdots & 0 & 0 & \cdots & 0 & 0 & \cdots & s p_{i, t, 100}^{f} & 0 & 0 & 0 & \cdots & 0 \\
0 & 0 & \cdots & 0 & 0 & \cdots & 0 & 0 & \cdots & 0 & 0 & s p_{i, t, 0}^{m} & 0 & \cdots & 0 \\
0 & 0 & \cdots & 0 & 0 & \cdots & 0 & 0 & \cdots & 0 & 0 & 0 & s p_{i, t, 1}^{m} & & 0 \\
\vdots & \vdots & & \vdots & \vdots & & \vdots & \vdots & & \vdots & \vdots & \vdots & & \ddots & \\
0 & 0 & \cdots & 0 & 0 & \cdots & 0 & 0 & \cdots & 0 & 0 & 0 & 0 & & s p_{i, t, 99}^{m} \\
0 & 0 & \cdots & 0 & 0 & \cdots & 0 & 0 & \cdots & 0 & 0 & 0 & 0 & \cdots & s p_{i, t, 100}^{m}
\end{array}\right] .
$$

Let $\mathrm{sp}^{f}{ }_{i, \mathrm{t}, \alpha}$ be the probability that a woman belonging to diocese $\mathrm{i}$ and aged $\alpha$ years in period $t$ survives until the beginning of period $t+1 . f \mathrm{r}_{\mathrm{t}, \alpha}$ is the number of girls a woman aged $\alpha$ years gives birth to during period $t$ and who survive until the beginning of period $t+1$. Accordingly, $s p_{i, t, a}^{m}$ is the survival probability for men and $f \mathrm{r}^{\mathrm{m}}{ }_{\mathrm{t}, \alpha}$ is the fertility rate for boys. As we set all fertility rates to zero, no zero-year church members initially live in period $t+1$. By multiplying by the Leslie matrix, we automatically correct $\mathrm{rc}_{\mathrm{i}, \mathrm{t}+1}$ for deaths. For survival probabilities, we use federal state-specific values (Statistisches Bundesamt 2018b). ${ }^{17}$ If a Protestant regional church or a diocese is located in several states, we weigh the survival probability according to the respective proportion of members in the federal states.

The course of the Catholic diocese- and Protestant regional church-specific likelihood of leaving the church is very similar nationwide, albeit as described in Section 2.2.4 at a different level. For the projection, we assume that the Catholic diocese- and Protestant regional church-specific likelihood of leaving the church remains constant at the increased level of 2013-2017 in the long term. To calculate deregistrations, we use the arithmetic mean of the deregistration rates of 2013-2017. We weigh these deregistrations with the age- and gender-specific distribution of deregistrations in 2017, so that:

$$
\boldsymbol{d} \boldsymbol{r}_{r c_{i}, t}=\boldsymbol{r} \boldsymbol{c}_{i, t} * \boldsymbol{L} \boldsymbol{M}_{i, t} * \frac{d r_{r c_{i}, 2017}}{\overline{d r_{r c_{i}, 2017}}} * \frac{1}{5} \sum_{s=2013}^{2017}\left(\frac{\overline{d r}_{r c_{i}, s}}{\overline{r c}_{i}, s}\right) .
$$

$\overline{\mathrm{dr}}_{\mathrm{rc}_{\mathrm{i}}, \mathrm{s}}$ is the total number of members leaving the church in diocese $\mathrm{i}$ in year $\mathrm{t}$, i.e. $\overline{\mathrm{rc}_{\mathrm{i}, \mathrm{t}}}$ is the total number of members of diocese $\mathrm{i}$ in year $\mathrm{t}$. We calculate the number of people joining the church accordingly.

17 Upon reaching the maximum age, we assume a survival probability of 0 percent. See Bonin (2001: 245). 
For the calculation of baptisms, we distinguish between those of children up to the age of six and those of people older than seven. For baptisms up to the age of six, we use the number of births $\left(\mathrm{c}_{\mathrm{ri}_{\mathrm{i}}, \mathrm{t}+1}\right)$, calculated with age-specific fertility:

$$
\begin{aligned}
& c_{r c_{i}, t+1}^{f}=\boldsymbol{f} \boldsymbol{r}^{\boldsymbol{f} *} \boldsymbol{r} \boldsymbol{c}_{\boldsymbol{i}, \boldsymbol{t}}^{\boldsymbol{f}}, \\
& c_{r c_{i}, t+1}^{m}=\boldsymbol{f} \boldsymbol{r}^{\boldsymbol{m} *} \boldsymbol{r} c_{\boldsymbol{i}, \boldsymbol{t}}^{\boldsymbol{f}} .
\end{aligned}
$$

Let $f \mathrm{r}^{f}$ be a column vector with 101 entries, which contains the age-specific fertility rates for girls $\left(f r_{t, a}^{f}\right)$, where $f r_{t, a}^{f}$ is greater than zero only for women of childbearing age between 15 and 49 years. We construct $f \mathrm{rm}$ accordingly for male live births. Let $\mathrm{rc}_{\mathrm{i}, \mathrm{t}}^{f}$ be a row vector containing, according to the structure of $\mathrm{rc}_{\mathrm{i}, \mathrm{t}}$, only the first 101 entries (and thus, only the female share) of the membership structure.

We calculate baptisms of 0 to 6 year olds as gender- and age-specific shares in the total fertility rates within a diocese. As in the case of people joining and leaving the church, we use a five-year average of baptisms. Because there are no actual figures for births, we provisionally use only the calculated births of the base year to determine the proportion of baptized births, so that:

$$
b_{t+1, q}^{f}=\frac{1}{5} \sum_{s=2013}^{2017} \frac{b_{t, q}^{f} * c_{2017}^{f}}{\sum_{r=0}^{6} b_{s, r}^{f}} * c_{t+1}^{f} .
$$

For male baptisms, we proceed accordingly. The ratio of baptisms of children to the total number of children a Catholic (or Protestant) mother gives birth to seems to be relatively stable over the course of time (see Section 2.2.3). Therefore we assume that the ratio is permanently constant. To determine the number of baptisms after the age of seven, we calculate them according to the procedure for people joining and leaving the church.

We divide the total migration into internal and external migration, so that:

$$
m_{r c_{i}, t}=m_{r c_{i}, t}^{i n t}+m_{r c_{i}, t}^{e x t}
$$

For internal migration of Catholics (and Protestants), we use the migration flows of 2013 between the 28 Catholic dioceses (and 20 Protestant regional churches). These flows were measured in a special evaluation of the Federal Statistical Office for the two major churches. This evaluation provides the migration flows of Catholics (and Protestants) between Catholic dioceses (and Protestant regional churches). The internal migration of a diocese corresponds to the difference between immigration from other dioceses and emigration to other dioceses, so that

$$
\boldsymbol{m}_{\boldsymbol{r} c_{i}, t}^{i n t}=\left(\sum_{j=1}^{28}\left(\frac{\bar{m}_{2013}^{i, j}}{\sum_{i=1}^{28} \bar{m}_{2013}^{i, j}} * \overline{r c_{l, t}}\right)-\sum_{i=1}^{28}\left(\frac{\bar{m}_{2013}^{i, j}}{\sum_{j=1}^{28} \bar{m}_{2013}^{i, j}} * \overline{r c_{l, t}}\right)\right) * \boldsymbol{m}^{i n t}
$$


$\bar{m}_{2013}^{i, j}$ represents the absolute number of migrations from diocese $\mathrm{j}$ to diocese $\mathrm{i}$ in 2013. We construct $m^{\text {int }}$ as a row vector according to $p_{t}$. It represents the age- and gender-specific distribution of the internal migration flows.

To determine external migration, we adopt a multi-year average from 2000-2013 without 2008, which was affected by a statistical adjustment. For the calculation of immigration into the Protestant church, we assume the arithmetic mean permanently. As described in Section 2.2.2, the potential of Catholic migrants will decline over the coming decades, so that for Catholic immigration, we expect a linear decrease of 65 percent of the baseline between 2025 and 2040. We divide the absolute figures according to the age and gender of external migration to the Federal Republic of Germany in 2015.

To project the remainder of the total population, we first multiply $\mathrm{rp}_{t}$ by the valid Leslie Matrix for the entire German population in t, and then adjust for church-specific factors such as baptisms and people joining and leaving the church. Thus, the remaining population results in the following year as:

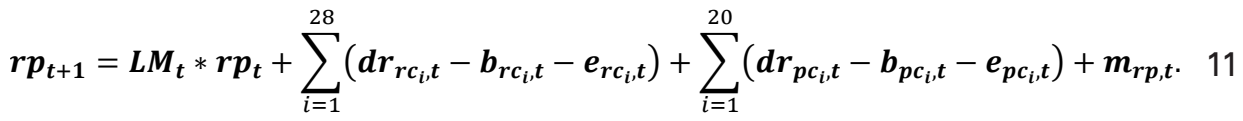

$m_{\mathrm{rp}, \mathrm{t}}$ describes external migration, which we adjust for denominational migration flows, so that:

$$
\boldsymbol{m}_{r p, t}=\boldsymbol{m}_{\bar{P}, t}^{\underline{e x t}}-\sum_{i=1}^{28} \boldsymbol{m}_{r c_{i}, t}^{\text {ext }}-\sum_{i=1}^{20} \boldsymbol{m}_{\boldsymbol{p c}_{i}, t}^{\boldsymbol{e x t}} .
$$

\section{$4 \quad$ Projection results}

\subsection{Membership development}

If the trend of recent years continues in the future, by 2060, the number of church members in Germany will be almost half that of today. Figure 5 shows how the number of Protestants, Catholics and the remaining population might develop in the long term. From 1995 to the mid-2020s, the number of the total population, with slight fluctuations, remains relatively stable at around 82 million. Until 2060, we observe a continuous decline to $\mathbf{7 2 . 9 5}$ million. The picture is different for registered church members. Although they numbered 55.64 million in 1995, by 2017, they reduced by 10.79 million (to 44.85 million). Until 2060, the number would continue to decrease to 22.65 million. Thus, the absolute number of church members in 2060 would be about 50.5 percent of the 2017 count. For the Catholic Church, this would mean a decrease from 23.30 million church members in 2017 to 12.15 million in 2060 (a decrease of 11.15 million). In the same period, the number of Protestants would fall from 21.53 million to 10.50 million (a decrease of 11.03 million).

The decline in the absolute number of registered church members is reflected in the proportion of Protestants and Catholics in the total population. Due to demographic changes, the number of the total population would also decrease, but much 
Fig. 5: $\quad$ Projected development of total population and church members in Germany, between 1995-2060

Population in millions
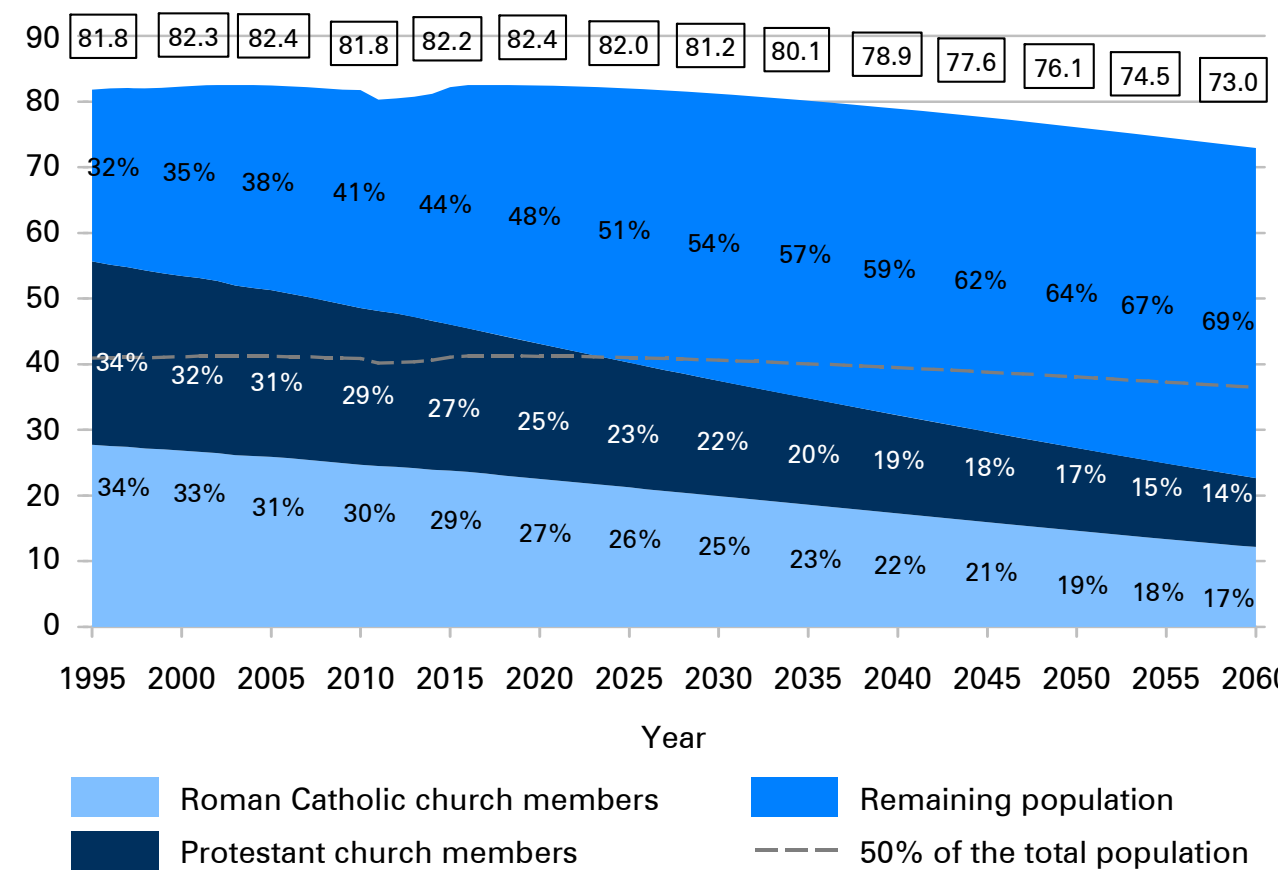

Source: own calculation based on Kirchenamt der EKD (2018b); Verband der Diözesen Deutschlands (2018); Statistisches Bundesamt (2015, 2018b/c). Percentages describe the corresponding proportion of the total population.

less dramatically. Due to church-specific factors such as baptism, deregistration, and joining the church, the share of registered church members in the total population would continue to decline steadily. In 2060, only 31.1 percent of the population would be registered as Protestant or Catholic. In 1960, however, the proportion of registered church members in the total West German population was about 93.7 percent (Sekretariat der Deutschen Bischofskonferenz 2018, Table 7.24, own calculation). 2024 marks a turning point in terms of church membership in Germany: From then on, it is no longer a majority of the people living in Germany registered with either of the two major churches. By 2030, the annual relative losses would amount to about 1.4 percent of the total members. Thereafter, the relative loss would grow to 1.8 percent annually by 2060 .

Looking at the decline of church members in the year 2060, we observe only minor differences between the two denominations. Compared to 2017, the Catholic Church would lose 47.8 percent by 2060 , a slightly lower share than the Protestant Church, with 51.2 percent. The slower decline is due to the greater Catholic immigration from abroad. When external migrations are not taken into account, the difference in membership decline between the Catholic Church (-51.2 percent) and the 
Protestant Church (-52.9 percent) decreases. The different age structure is another distinguishing feature.

As the average age of church members increases, there are less members of younger age cohorts. Because young people between the ages of 25 and 35 have a higher likelihood of leaving the church, the annual proportion of people leaving the church in all registered members would subsequently fall from 0.8 percent to 0.7 percent during the projection period. The rate of people joining the church would remain almost constant until 2060. A larger decline can be observed in baptisms. While 42.3 percent of all children born in Germany in 2017 were baptized, this rate would be only 22.5 percent in 2060 . The absolute number of baptisms would decrease by almost 60.3 percent. Due to the greater life expectancy and the lower tendency to leave the church, the proportion of women among church members would increase slightly, from 53.8 percent to 54.4 percent, during the projection period.

\subsection{Age structure}

In 2017, church members were older than the total population. Moreover, the more recent birth cohorts are also relatively small. With reference to the total population, we find that fewer church members are under the age of 20 (15.9 vs. 18.3 percent of the total population), there are fewer church members between the ages of 20 and 64 (58.2 vs. 60.2 percent) and more are older than 65 years (25.9 vs. 21.5 percent). This distribution varies greatly between the individual Catholic dioceses and Protestant regional churches.

Figure 6 shows the projected changes in age structure of church members in Germany up until 2060. In the base year 2017, the largest age cohorts are the baby boomers between the ages of 45 and 65 years old. These age cohorts will shift up in the coming years. Three bulges of the membership structure stand out: baby boomers age 45 to 65 , their parents age 75 to 85 and their children age 20 to 35 . At the beginning of the projection period, these children are in their reproductive ages. This explains the currently increased number of births in Germany (the baby boomers' grandchildren). Between 2025 and 2035, baby boomers will reach retirement age. Then there is the strongest shift between the working population aged 20 to 64 and the age group over 64. The age structure for the year 2040 illustrates the long-term nature and persistence of population-dynamic processes (Statistisches Bundesamt 2015: 5). Not only the children, but also the grandchildren of the baby boomers are visible.

Another 20 years later, in 2060, the children of today's baby boomers will be around 70 years old. Due to the assumed baptism and deregistration behaviour (Fig. 6), we can no longer detect the grandchildren of the baby boomers who would be about 40 years of age in 2060; in the state population of 2060, we can clearly observe these cohorts.

To reveal the expected age process, we divide the age distribution in Figure 6 into three age groups. In 2017, 25.9 percent of church members were over the age of 64; this share was higher among the Protestant Church (28.0 percent) than among the Catholic Church (24.1 percent). At the end of the projection period, 40.4 percent of 
Fig. 6: Projected age structure of Protestants and Catholics in Germany, 2017, 2040, and 2060
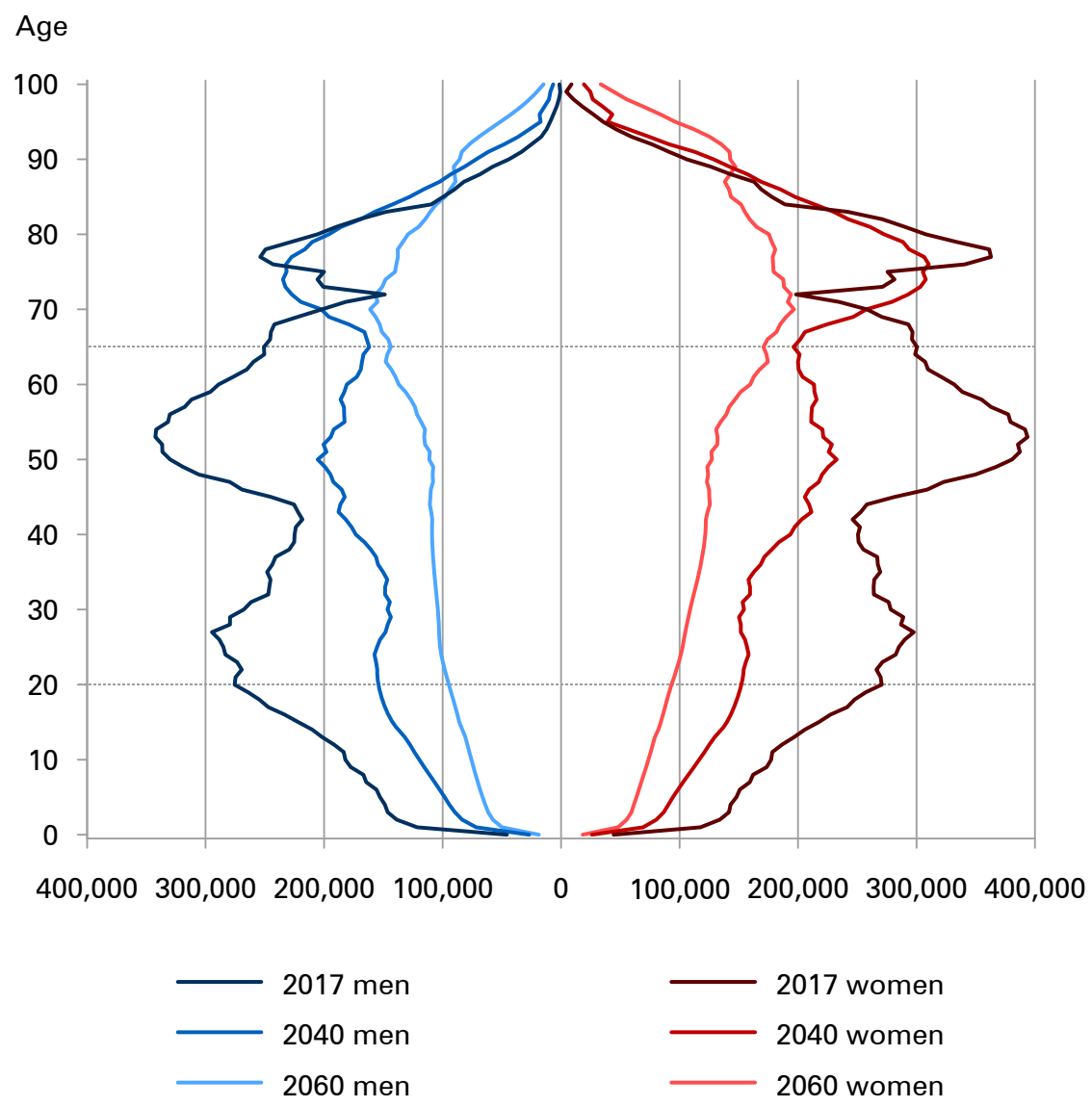

Source: own calculation based on Kirchenamt der EKD (2018b); Verband der Diözesen Deutschlands (2018); Statistisches Bundesamt (2015, 2018b/c).

registered church members would be older than 64 years. The difference between the denominations would continually decrease. In 2060, 41.1 percent of Catholics and 39.5 percent of Protestants would be older than 64 years. Consequently, the Catholic Church would lose relatively more members after 2060.

We estimate a similar, but less pronounced, increase in the total population for the over-64 age group, from 21.5 percent in 2017 to 32.5 percent in 2060 . The number of working age people in Germany between the ages of 20 and 64 would fall by 25.7 percent, from 49.67 million in 2017 to 36.86 million in 2060 . The number of church members of working age would fall from 26.08 million to 10.66 million during the same period (-59.1 percent). These changes in membership structure would influence the churches' pastoral services. The changes would also have an impact on church tax revenue, and from the perspective of the churches as employers, on the labour supply. 


\subsection{Regional distribution}

In 2017, more than three-quarters of Catholics and Protestants in Germany lived in a Catholic diocese or Protestant regional church in western or southern Germany. This general distribution within Germany would also persist over the projection period. All four regions will lose church members. Losses would be somewhat lower in southern Germany and strongest in eastern Germany. According to our calculations, in the year 2060 only 1.49 million Christians would live in eastern Germany (see Table 2). Based on the state population in this region of Germany, this number would correspond to a Christian share of about 12.4 percent in the total population. $^{18}$

Tab. 2: $\quad$ Projected regional distribution of church members in Germany, 2017 and 2060

\begin{tabular}{|c|c|c|c|c|c|c|c|c|c|c|}
\hline & \multicolumn{2}{|c|}{ North } & \multicolumn{2}{|c|}{ East } & \multicolumn{2}{|c|}{ West } & \multicolumn{2}{|c|}{ South } & \multicolumn{2}{|c|}{ Total } \\
\hline & 2017 & 2060 & 2017 & 2060 & 2017 & 2060 & 2017 & 2060 & 2017 & 2060 \\
\hline \multicolumn{11}{|l|}{ Church members } \\
\hline in millions & 7.59 & 3.71 & 3.21 & 1.49 & 17.30 & 8.45 & 16.73 & 9.00 & 44.83 & 22.65 \\
\hline $\begin{array}{l}\text { in relation to } 2017 \text { (in percent) } \\
\text { in percent of the total }\end{array}$ & & 48.9 & & 46.4 & & 48.9 & & 53.8 & & 50.5 \\
\hline population & 51.5 & 29.1 & 22.3 & 12.4 & 67.0 & 36.9 & 62.4 & 35.4 & 54.3 & 31.0 \\
\hline \multicolumn{11}{|l|}{ Protestant } \\
\hline in millions & 5.77 & 2.66 & 2.40 & 1.01 & 7.30 & 3.58 & 6.06 & 3.25 & 21.53 & 10.50 \\
\hline $\begin{array}{l}\text { in relation to } 2017 \text { (in percent) } \\
\text { in percent of the total }\end{array}$ & & 46.1 & & 42.1 & & 49.1 & & 53.6 & & 48.8 \\
\hline population & 39.1 & 20.8 & 16.7 & 8.4 & 28.3 & 15.6 & 22.6 & 12.8 & 26.1 & 14.4 \\
\hline \multicolumn{11}{|l|}{ Catholic } \\
\hline in millions & 1.82 & 1.05 & 0.81 & 0.48 & 10.00 & 4.87 & 10.66 & 5.75 & 23.30 & 12.15 \\
\hline $\begin{array}{l}\text { in relation to } 2017 \text { (in percent) } \\
\text { in percent of the total }\end{array}$ & & 57.6 & & 59.1 & & 48.7 & & 54.0 & & 52.2 \\
\hline population & 12.4 & 8.2 & 5.7 & 4.0 & 38.7 & 21.2 & 39.8 & 22.6 & 28.2 & 16.7 \\
\hline
\end{tabular}

Source: own calculation based on Kirchenamt der EKD (2018b); Verband der Diözesen Deutschlands (2018); Statistisches Bundesamt (2015, 2018b/c).

The starting point and the development is different for the two denominations. In 2017, the members of the Protestant Church in Germany are spread evenly with the exception of eastern Germany. In contrast, only 2.63 million of the 23.30 million Catholics belong to a diocese in northern or eastern Germany, respectively. The remaining 20.66 million Catholic church members live in western or southern Germany. Because of this unequal distribution, the losses would be lower in the

\footnotetext{
18 As we do not project the total population in the federal states but only in the whole of Germany, we refer to variant 2 of the state population projection for regional analysis of the total population in 2060. See Statistisches Bundesamt (2015).
} 
regions with fewer Catholics in northern and eastern Germany than in southern and western Germany. This would be mainly due to internal migration. Anyone moving from southern or western Germany to northern Germany (Hamburg in particular) or eastern Germany (Berlin in particular) would be more likely to be Catholic than those who move in the opposite direction. In relative terms, Protestant regional churches would lose most members in eastern Germany. This is due to the age structure. In 2017, 35.2 percent of all Protestants living in eastern Germany were 65 years or older. The corresponding value for all Protestants in Germany is 28.0 percent. At the end of the projection period, this difference would be balanced (40.4 percent and 39.5 percent).

\section{Scenarios}

The results show a trend of how membership could develop in the coming years, but are not a one-to-one prediction (Pötzsch 2016: 38). We assume that the trend of recent years is also representative of the future. If the value of individual influential factors changes in the long term, the results will differ from the actual development. Therefore, in this section, we show how changes in the framework conditions affect the projection results. We show an overview of the scenarios "no external migration", "only demography", "higher fertility", "secularisation" and "evangelisation" in Figure 7 and Table 3.

Tab. 3: $\quad$ Scenarios for projected church memberships, 2017-2060

\begin{tabular}{lllllllllll}
\hline & 2017 & 2020 & 2025 & 2030 & 2035 & 2040 & 2045 & 2050 & 2055 & 2060 \\
\hline Baseline & 44.85 & 43.08 & 40.23 & 37.46 & 34.79 & 32.20 & 29.69 & 27.23 & 24.85 & 22.65 \\
No External Migration & 44.85 & 42.93 & 39.84 & 36.86 & 34.02 & 31.31 & 28.68 & 26.11 & 23.64 & 21.34 \\
Higher Fertility & 44.85 & 43.08 & 40.25 & 37.52 & 34.91 & 32.38 & 29.93 & 27.54 & 25.24 & 23.13 \\
Only Demography & 44.85 & 44.32 & 43.48 & 42.57 & 41.55 & 40.37 & 39.09 & 37.80 & 36.57 & 35.42 \\
Secularisation & 44.85 & 43.02 & 39.93 & 36.76 & 33.59 & 30.44 & 27.34 & 24.29 & 21.36 & 18.65 \\
Evangelisation & 44.85 & 43.11 & 40.42 & 37.91 & 35.58 & 33.38 & 31.30 & 29.31 & 27.42 & 25.72 \\
\hline
\end{tabular}

Source: own calculation based on Kirchenamt der EKD (2018b); Verband der Diözesen Deutschlands (2018); Statistisches Bundesamt (2015, 2018b/c).

\subsection{No External Migration}

The projection is based on annual external migration to the two major churches of about 50,000 people, which would decrease to 24,000 between 2025 and 2040 . Due to immigration from the predominantly Catholic countries of Croatia, Italy, and Poland, the Catholic Church, with an external migration balance of 40,000 persons in 2017, would benefit considerably more than the Protestant Church. In contrast to fertility and mortality, migration is subject to strong fluctuations. Therefore, deriving a trend for the future is difficult (Statistisches Bundesamt 2015: 37-41). This 
Fig. 7: $\quad$ Scenarios for projected church memberships, 2017-2060

Church members in million

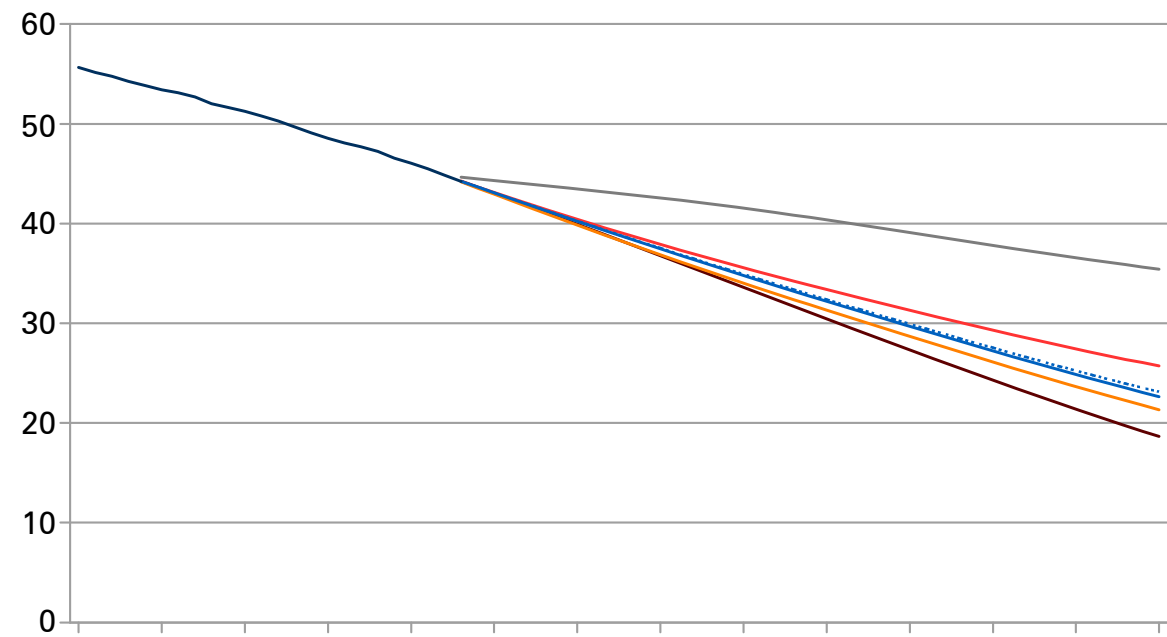

19952000200520102015202020252030203520402045205020552060 Year

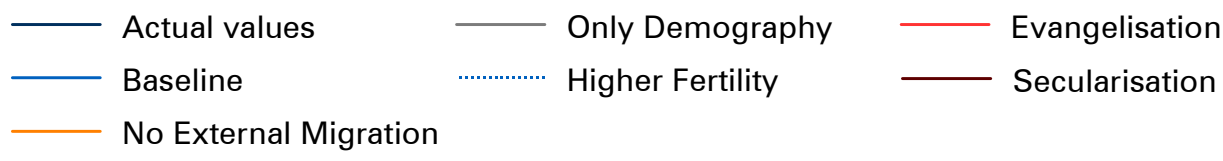

Source: own calculation based on Kirchenamt der EKD (2018b); Verband der Diözesen Deutschlands (2018); Statistisches Bundesamt (2015, 2018b/c).

is why we calculate a scenario without external migration. If we ignore external migration flows, both churches will lose another 1.31 million members by 2060 . The number of registered church members would be 21.34 million, 11.27 million of which would be Catholic (-0.89 million) and 10.08 million Protestant (-0.42 million). ${ }^{19}$

\subsection{Higher Fertility}

Although relevant studies have suggested a higher fertility of religious people compared to non-religious people (Peri-Rotem 2016; Frejka/Westoff 2008: 23), we were able to show that the fertility of registered church members is not higher than that of non-members. If we continue to assume that people who are no longer religious leave the two churches (Riegel et al. 2018: 187-189), this could lead to a steadily increasing proportion of religious people among the remaining church members. Accordingly, the total fertility rate of church members could rise in the coming dec-

19 Deviations result from rounding. 
ades, and in the long run, equal the observed level of religious people. Therefore, we examine how a continuously increasing total fertility rate would affect membership development. Moreover, it is likely that the likelihood of leaving the church would decrease if religion among church members is higher. However, to isolate the impact, we only consider a higher fertility in this scenario. We expect a linear increase in the combined total fertility rate, from 1.5 in 2017 to 1.7 in 2060. That would mean 0.48 million more church members ( +2.1 percent) than calculated in the baseline scenario. Consequently, an increase in fertility would have only a small impact on declining membership.

\subsection{Only Demography}

To examine how strong demographic changes affect the membership of both churches, we assume a scenario with no people actively joining or leaving the church. Moreover, we assume that every child a Protestant or Catholic mother gives birth to is baptized at birth. Consequently, this scenario includes only demographic factors, that is, the number of children a Protestant or Catholic mother gives birth to, the deaths of registered church members and the external migration balance of Protestants and Catholics.

Demographic changes alone lead to a decrease in membership from 44.85 million to 35.42 million (21.0 percent). Consequently, declining registered membership would be only about one third due to demographic change. Two-thirds would be due to church-specific factors. If we also take these into account, i.e. baptism and people leaving and joining the church, the membership of both churches would be 22.65 million in 2060. The difference in the demography-related development of 12.77 million church members is due to 5.31 million fewer baptisms of children, a negative balance of 8.87 million people joining and leaving the church and 1.41 million deaths of church members who have left the church since the base year. ${ }^{20}$ Of the total membership decline, 28.5 percentage points are attributable to churchspecific factors.

Therefore, church-specific factors would influence the overall decline more strongly than demographic factors. Especially in the first years of the projection, the children of the baby boomers would be between 20 and 35 years old, when the likelihood of leaving the church is highest. Therefore, deregistration would be particularly high, and fewer births and baptisms would take place. In the 15 years between 2025 and 2040, the births by Protestant and Catholic mothers would fall by 33.7 percent. Because the deaths of church members would also fall by 14.6 percent during the same period, the impact of demographic factors would steadily increase. These opposing trends would intersect around the year 2040. Subsequently, the annual demographic decline would be stronger than the church-related decline. The churches can only address the issue of declining membership through influencing baptism behaviour, as well as the tendencies to join or leave the church.

${ }^{20}$ Church members who left the church since 2017 and died by 2060. 


\subsection{Secularisation and evangelisation}

Nevertheless, many pertinent studies suggested that the likelihood of leaving the church may continue to increase, and the trend toward secularisation of society will continue (Pollack/Rosta 2015: 223; Voas/Doebler 2011: 59-60; Voas/Crockett 2005: 24; Ebertz 2005: 42; Norris/Inglehart 2004: 24-27). In a secularisation scenario, therefore, we gradually double the age- and gender-specific likelihood of leaving the church until 2060. At the same time, we suggest a continuously decreasing age- and gender-specific likelihood of being baptized as an adult and joining the church to 50 percent of the value in 2017 . With these assumptions, 4.00 million fewer people would be registered church members in 2060. Compared to the baseline scenario, this corresponds to a further decrease of 8.9 percent. During the projection period, about 0.48 million fewer people would be baptized as adults or join the church, and 3.39 million more people would leave the church.

In contrast to the secularisation theory, fewer scientists postulate a revival of religion (Riesebrodt 2000; Graf 2004). We consider this thesis unlikely, but theoretically possible. Therefore, we analyse the reverse case in an evangelisation scenario: a gradually decreasing age- and gender-specific likelihood of leaving the church until 2060 by 50 percent, and at the same time, a continuously doubling age- and gender-specific likelihood of being baptized as an adult and joining the church until 2060. In this scenario, 3.07 million more people would be registered as Catholic or Protestant, and thus, 6.9 percent more than the baseline scenario. About 2.00 million fewer people would leave the churches, and 0.97 million more people would be baptized as an adult or join the church.

For the two denominations, the effects are different. In the secularisation scenario, 54.3 percent of the total decrease of 4.00 million Christians would be attributable to the Protestant Church, and 45.7 percent to the Catholic Church. However, the Protestant Church would also gain significantly more members in the evangelisation scenario: 61.1 percent of the 3.07 million members in this scenario would be Protestant, and 38.9 percent Catholic. The fact that the Protestant Church is more affected by these two scenarios is linked to the higher number of people joining and leaving the church, which are church-specific factors. There is more movement between the members of the Protestant Church and non-members.

\section{Conclusion}

With the present projection of members for the Protestant and Catholic churches in Germany, we have shown that by the year 2060 both churches would lose almost half of their registered members if present trends continue. Protestant Church membership would shrink slightly more than Catholic Church membership, which is essentially due to less external migration and an older age structure. The proportion of church members in the total population would decrease nationwide from 54.4 percent in 2017 to 31.1 percent in 2060. Thus, Hypothesis 1 is supported. 
The reasons for decline include demographic and church-specific influences. Demographic changes would more severely affect the two churches than the total population. Although the number of inhabitants in Germany is projected to decrease by 11.6 percent by 2060 , the decline due to demographic factors in the churches would be 21.0 percent of the 2017 membership. This deviant development has two reasons. The total population is more likely to benefit from external migration. Although the confessional migration balance would continue to be around 0.1 percent of all members, the share of total population would increase from 0.3 to 0.6 percent. In addition, the relative decline due to the excess of deaths over births in the two churches would be, on average, more than twice as large as that of the total population. Thus, Hypothesis 2 is also supported.

The question of whether church-specific influences would play a greater role than demographic influences results in a more differentiated picture. Overall, churchspecific factors would have a greater impact on the decline in membership than demographic ones. Although there would be 9.42 million fewer church members (-21.0 percent) by 2060 for demographic reasons alone, the drop due to church-specific factors would total an additional 12.77 million (-28.5 percent). In particular, the development of the number of people leaving the church has been very volatile over time. Therefore, it is conceivable that the parameterisation of the baseline scenario would not be achieved in the long term. We were able to show in a secularisation scenario and in an evangelisation scenario that continuously changing behaviour in leaving and joining the church can lead to significant changes in membership development. There is a difference of 7.07 million registered church members in the year 2060 between the scenarios we chose. If there are any promising approaches for churches to slow down membership decline, then they should look at these three factors. ${ }^{21}$ Looking at the influence of both categories (demographic and churchspecific influences) over time, we remark that the impact of church-specific factors is decreasing. From the mid-2040s onwards, demographic factors would have a greater impact on membership decline. Therefore, Hypothesis 3 is only partially supported.

An ambiguous picture also emerges in the case of Hypothesis 4. Higher deregistration and lower baptism rates in regions with a lower proportion of Christians in the total population would exacerbate regional disparities. However, internal migration would counteract these church-specific effects, as the denominational internal migration flows to diaspora regions tend to be stronger than in regions with a high proportion of Christians.

Of course, such a long-term projection based on what-if assumptions is not a precise prediction (Pötzsch 2016: 38). Nonetheless, it provides new, deep insights into the structure and development of church membership in Germany. From the present projection results, the two churches could derive processes for dealing with the cost-intensive areas of staff and infrastructure. In addition, this project clarifies

21 To what extent strategic decisions made by the church management can actually influence church-specific factors is not the subject of this study. 
the relevance of church-specific factors, and identifies the influence of baptism, joining and leaving behaviour as ultimately the only strategic starting points for longer-term planning by the churches. Due to the many subsidiary maintained facilities, decisions by church management have consequences for the state. These decisions will affect citizens and decision-makers at the federal, state and local levels.

Finally, demographic changes would hit the churches even harder than the total population. However, demographic changes would not be the main reason for the long-term development. Instead, church-specific factors, such as the number of baptisms, and members leaving and joining the church, and therefore, the longterm declining number of children born to a Catholic or Protestant mother would be responsible for the decline in membership reported in this article.

\section{Acknowledgements}

We are grateful to the anonymous referees of CPoS and Professor Philip Rees, the former editor of this journal, for their insightful comments and suggestions that improved the paper. We are also grateful to Professor Wolfgang Ilg, and Gerrit Manthei who also provided very useful suggestions. The research received financial support from the German Bishops' Conference (DBK) and the Evangelical Church in Germany (EKD).

\section{References}

Benz, Tobias; Hagist, Christian; Raffelhüschen, Bernd 2011: Projektion des Kirchensteueraufkommens und der Katholikenzahl im Erzbistum Köln. Studie im Auftrag des Erzbistums Köln. Freiburg: Forschungszentrum Generationenverträge der Albert-Ludwigs-Universität Freiburg.

Benz, Tobias; Raffelhüschen, Bernd 2013: Projektion des Kirchensteueraufkommens und der Katholikenzahl im Bistum Limburg. Studie im Auftrag des Bistums Limburg. Freiburg: Forschungszentrum Generationenverträge der Albert-Ludwigs-Universität Freiburg.

Bonin, Holger 2001: Generational Accounting. Theory and Application. Berlin/Heidelberg: Springer-Verlag [doi: 10.1007/978-3-662-04595-4].

Bowley, Arthur Lyon 1924: Births and Population in Great Britain. In: The economic journal: the journal of the Royal Economic Society 34,134: 188-192.

Burkimsher, Marion 2014: Is Religious Attendance Bottoming Out? An Examination of Current Trends Across Europe. In: Journal for the Scientific Study of Religion 53,2: 432-445 [doi: 10.1111/jssr.12111].

Cannan, Edwin 1895: The probability of a cessation of the growth of population in England and Wales during the next century. In: The economic journal: the journal of the Royal Economic Society 5,20: 505-515.

Ebertz, Michael N. 2005: Religion, Christentum und Kirche in den Pluralen Gesellschaften Europas, In: Schreiner, Peter; Sieg, Ursula; Elsenbast, Volker (Eds.): Handbuch Interreligiöses Lernen. Gütersloh: Gütersloher Verlagshaus: 41-56. 
Eicken, Joachim; Schmitz-Veltin, Ansgar 2010: Die Entwicklung der Kirchenmitglieder in Deutschland. Statistische Anmerkungen zu Umfang und Ursachen des Mitgliederrückgangs in den beiden christlichen Volkskirchen. In: WISTA - Wirtschaft und Statistik 6: 576-589.

Fetzer, Stefan 2005: Determinanten der zukünftigen Finanzierbarkeit der GKV: Doppelter Alterungsprozess, Medikalisierungs- vs. Kompressionsthese und medizinisch-technischer-Fortschritt, Diskussionsbeiträge / Institut für Finanzwissenschaft der Albert-Ludwigs-Universität Freiburg im Breisgau, No. 130.

Frejka, Thomas; Westoff, Charles F. 2008: Religion, Religiousness and Fertility in the U.S. and in Europe. In: European Journal of Population/Revue Européenne de Démographie 24,1: 5-31.

George, M. V. et al. 2004: Population Projections. In: Siegel, Jacob; Swanson, David (Eds.): The Methods and Materials of Demography. San Diego: Elsevier Academic Press: 561-601.

Goujon, Anne; Jurasszovich, Sandra; Potančoková, Michaela 2017: Religious Denominiations in Austria. Baseline study for 2016 - Scenarios until 2046. ÖIF Forschungsbericht.

Graf, Friedrich Wilhelm 2004: Die Wiederkehr der Götter. Religion in der modernen Kultur. München: Beck.

Hackett, Conrad et al. 2011: Global Christianity: A Report on the Size and Distribution of the World's Christian Population. Washington: Pew Research Center.

Hackett, Conrad et al. 2015: The Future of World Religions: Population Growth Projections, 2010-2050. Washington: Pew Research Center.

Halm, Dirk; Sauer, Martina 2017: Muslime in Europa. Integriert, aber nicht akzeptiert? Gütersloh: Bertelsmann Stiftung.

Kirchenamt der EKD 2018a: Gezählt 2018. Zahlen und Fakten zum kirchlichen Leben. Hannover.

Kirchenamt der EKD 2018b: Kirchenmitglieder, (Wieder-)Aufnahmen, Kasualien, Kirchenaustritte, Kirchensteuern und Kirchgeld von 1991 bis 2017. Aufbereitung für das Forschungszentrum Generationenverträge. Hannover.

Kirchenamt der EKD 2018c: Pressemitteilung der EKD vom 20.07.2018 “EKD-Statistik: Demografischer Wandel macht Kirche weiter zu schaffen." Hannover.

Lerch, Mathias et al. 2010: Religious Affiliation and Mortality in Switzerland, 1991-2004. In: Population English Edition 65,2: 217-250 [doi: 10.3917/popu.1002.0239].

Leslie, Patrick H. 1945: On the use of matrices in certain population mathematics. In: Biometrika 33: 183-212 [doi: 10.1093/biomet/33.3.183].

Norris, Pippa; Inglehart, Ronald 2004: Sacred and Secular. In: Religion and Politics Worldwide. Cambridge: Cambridge Univ. Press.

Peri-Rotem, Nitzan 2016: Religion and Fertility in Western Europe: Trends Across Cohorts in Britain, France and the Netherlands. In: European Journal of Population 32,2: 231-265 [doi: 10.1007/s10680-015-9371-z].

Petersen, Jens 2017: Kirchensteuer kompakt: Strukturierte Darstellung mit Berechnungsbeispielen. 3rd ed. Wiesbaden: Springer Gabler [doi: 10.1007/978-3-658-10631-7].

Pollack, Detlef; Rosta, Gergely 2015: Religion in der Moderne. Ein internationaler Vergleich. Frankfurt am Main: Campus Verlag. 
Pötzsch, Olga 2016: (Un-)Sicherheiten der Bevölkerungsvorausberechnungen. Rückblick auf die koordinierten Bevölkerungsvorausberechnungen für Deutschland zwischen 1998 und 2015. In: WISTA - Wirtschaft und Statistik 4: 36-53.

Rees, Philip H.; Wilson, Alan G. 1977: Spatial population analysis. 1. Aufl. London: Edward Arnold.

Riegel, Ulrich et al. 2019: Does Church Tax Matter? The Influence of Church Tax on Leaving the Church. In: International Journal of Practical Theology 23,2: 168-187.

Riegel, Ulrich; Kröck, Thomas; Faix, Tobias 2018: Warum Menschen die katholische Kirche verlassen. Eine explorative Untersuchung zu Austrittsmotiven im Mixed-Methods-Design. In: Etscheid-Stams, Markus; Laudage-Kleeberg, Regina; Rünker, Thomas (Eds.): Kirchenaustritt oder nicht - wie Kirche sich verändern muss. Freiburg: Herder: 125-207.

Riesebrodt, Martin 2000: Die Rückkehr der Religionen. Fundamentalismus und der 'Kampf der Kulturen'. München: Beck.

Rogers, Andrei 1967: Matrix analysis of interregional population growth and distribution. In: European congress // Regional Science Association 18: 177-196 [doi: 10.1111/ j.1435-5597.1967.tb01364.x].

Rogers, Andrei 1975: Introduction to multiregional mathematical demography. A WileyInterscience publication. New York: John Wiley \& Sons.

Sekretariat der Deutschen Bischofskonferenz 2018: Kirchliches Handbuch. Statistisches Jahrbuch der Bistümer im Bereich der Deutschen Bischofskonferenz. Bonn.

Statistisches Bundesamt 2015: Bevölkerung Deutschlands bis 2060. 13. koordinierte Bevölkerungsvorausberechnung. Wiesbaden.

Statistisches Bundesamt 2018a: Pressemitteilung Nr. 262 vom 13. Juli 2018: Mehr Sterbefälle und weniger Geburten im Jahr 2017.

Statistisches Bundesamt 2018b: Sterbetafel 2014/2016. Methoden- und Ergebnisbericht zur laufenden Berechnung von Periodensterbetafeln für Deutschland und die Bundesländer. Wiesbaden.

Statistisches Bundesamt 2018c: Wanderungen nach Religionszugehörigkeit. Sonderauswertung für die katholische und evangelische Kirche. Wiesbaden.

Statistisches Bundesamt 2018d: Sonderauswertung Kirchensteuer der Lohn- und Einkommensteuerstatistik für das Veranlagungsjahr 2014. Sonderauswertung für die evangelische und die katholische Kirche. Wiesbaden.

Statistisches Bundesamt 2018e: Methodenbeschreibung zur Sonderauswertung für die evangelische und die katholische Kirche. Lohn- und Einkommensteuerstatistik 2014. Wiesbaden.

Statistisches Bundesamt 2019: Bevölkerung und Erwerbstätigkeit 2016. Bevölkerungsfortschreibung auf Grundlage des Zensus 2011. Wiesbaden.

Verband der Diözesen Deutschlands 2018: Katholiken, (Wieder-)Aufnahmen, Kasualien, Kirchenaustritte von 2012 bis 2017. Freiburg.

Voas, David; Crockett, Alasdair 2005: Religion in Britain: Neither Believing nor Belonging. In: Sociology 39,1: 11-28 [doi: 10.1177/0038038505048998]

Voas, David; Doebler, Stefanie 2011: Secularization in Europe: Religious change between and within birth cohorts. In: Religion and Society in Central and Eastern Europe 4,1: 39-62.

Whelpton, Pascal Kidder 1928: Population of the United States. 1925 to 1975. In: American Journal of Sociology 34,2: 253-270. 
David Gutmann $(\bowtie)$, Fabian Peters. University of Freiburg, Research Center for Generational Contracts and Institute for Public Finance and Social Policy. Freiburg, Germany.

E-mail: david.gutmann@vwl.uni-freiburg.de,fabian.peters@vwl.uni-freiburg.de URL: http://www.fiwi1.uni-freiburg.de/ueber-uns/team/david_gutmann.shtml URL: http://www.fiwi1.uni-freiburg.de/ueber-uns/team/fabian_peters.shtml 


\section{Appendix}

Tab. A1: Regional assignment of Catholic (arch-)dioceses, Protestant regional churches, and federal states

\begin{tabular}{|c|c|c|}
\hline Catholic (Arch-)Dioecese & Protestant regional church & Federal state \\
\hline \multicolumn{3}{|c|}{ North } \\
\hline Hamburg & Braunschweig & Bremen \\
\hline Hildesheim & Bremen & Hamburg \\
\hline Osnabrück & Hannover & Mecklenburg-Vorpommern \\
\hline \multirow[t]{4}{*}{ Offizialatsbezirk Oldenburg } & Nordkirche & Niedersachsen \\
\hline & Oldenburg & Schleswig-Holstein \\
\hline & Reformierte Kirche & \\
\hline & Schaumburg-Lippe & \\
\hline \multicolumn{3}{|c|}{ East } \\
\hline Berlin & Anhalt & Berlin \\
\hline Dresden-Meißen & Berlin-Brandenburg- & Brandenburg \\
\hline Görlitz & schlesische Oberlausitz & Sachsen \\
\hline Erfurt & Mitteldeutschland & Sachsen-Anhalt \\
\hline Magdeburg & Sachsen & Thüringen \\
\hline \multicolumn{3}{|c|}{ South } \\
\hline Bamberg & Baden & Baden-Württemberg \\
\hline Eichstätt & Bayern & Bayern \\
\hline Speyer & Pfalz & Saarland \\
\hline Würzburg & Württemberg & Rheinland-Pfalz (50\%) \\
\hline \multicolumn{3}{|l|}{ Freiburg } \\
\hline \multicolumn{3}{|l|}{ Rottenburg-Stuttgart } \\
\hline \multicolumn{3}{|l|}{ München and Freising } \\
\hline \multicolumn{3}{|l|}{ Augsburg } \\
\hline \multicolumn{3}{|l|}{ Regensburg } \\
\hline \multicolumn{3}{|l|}{ Passau } \\
\hline \multicolumn{3}{|c|}{ West } \\
\hline Köln & Hessen und Nassau & Hessen \\
\hline Aachen & Kurhessen Waldeck & Nordrhein-Westfalen \\
\hline Essen & Lippe & Rheinland-Pfalz (50\%) \\
\hline Limburg & Rheinland & \\
\hline Münster without Offizialatsbezirk & Westfalen & \\
\hline \multicolumn{3}{|l|}{ Oldenburg } \\
\hline \multicolumn{3}{|l|}{ Trier } \\
\hline \multicolumn{3}{|l|}{ Mainz } \\
\hline \multicolumn{3}{|l|}{ Paderborn } \\
\hline Fulda & & \\
\hline
\end{tabular}

Source: Own representation 


\section{Comparative Population Studies}

wWw.comparativepopulationstudies.de

ISSN: 1869-8980 (Print) - 1869-8999 (Internet)

\section{Published by}

Prof. Dr. Norbert F. Schneider

Federal Institute for Population Research

D-65180 Wiesbaden / Germany

\section{(cc) BY-SA}

2020

\section{Managing Editor}

Prof. Dr. Johannes Huinink

Dr. Katrin Schiefer

\section{Editorial Assistant}

Beatriz Feiler-Fuchs

Wiebke Hamann

\section{Layout}

Beatriz Feiler-Fuchs

E-mail:cpos@bib.bund.de

\section{Scientific Advisory Board}

Karsten Hank (Cologne)

Michaela Kreyenfeld (Berlin)

Marc Luy (Vienna)

Natalie Nitsche (Rostock)

Zsolt Spéder (Budapest)

Rainer Wehrhahn (Kiel)

\section{Board of Reviewers}

Bruno Arpino (Barcelona)

Kieron Barclay (Rostock)

Laura Bernardi (Lausanne)

Gabriele Doblhammer (Rostock)

Anette Eva Fasang (Berlin)

Michael Feldhaus (Oldenburg)

Tomas Frejka (Sanibel)

Alexia Fürnkranz-Prskawetz (Vienna)

Birgit Glorius (Chemnitz)

Fanny Janssen (Groningen)

Frank Kalter (Mannheim)

Stefanie Kley (Hamburg)

Bernhard Köppen (Koblenz)

Anne-Kristin Kuhnt (Duisburg)

Hill Kulu (St Andrews)

Nadja Milewski (Rostock)

Roland Rau (Rostock)

Thorsten Schneider (Leipzig)

Tomas Sobotka (Vienna)

Jeroen J. A. Spijker (Barcelona)

Heike Trappe (Rostock)

Helga de Valk (The Hague)

Sergi Vidal (Barcelona)

Michael Wagner (Cologne) 